\title{
Adipose tissue browning in mice and humans
}

\author{
Carsten T Herz and Florian W Kiefer \\ Clinical Division of Endocrinology and Metabolism, Department of Medicine III, Medical University of Vienna, Vienna, Austria
}

Correspondence should be addressed to F W Kiefer: florian.kiefer@meduniwien.ac.at

\begin{abstract}
In the midst of an obesity epidemic, the promotion of brown adipose tissue (BAT) function and the browning of white adipose tissue (WAT) have emerged as promising therapeutic targets to increase energy expenditure and counteract weight gain. Despite the fact that the thermogenic potential of bone fide BAT in rodents is several orders of magnitudes higher than white fat containing brite/beige adipocytes, WAT browning represents a particularly intriguing concept in humans given the extreme amount of excess WAT in obese individuals. In addition, the clear distinction between classic brown and beige fat that has been proposed in mice does not exist in humans. In fact, studies of human BAT biopsies found controversial results suggesting both classic brown and beige characteristics. Irrespective of the true 'color', accumulating evidence suggests the induction of thermogenic adipocytes in human WAT depots in response to specific stimuli, highlighting that WAT browning may occur in both, mice and humans. These observations also emphasize the great plasticity of human fat depots and raise important questions about the metabolic properties of thermogenically active adipose tissue in humans and the potential therapeutic implications. We will first review the cellular and molecular aspects of selected adipose tissue browning concepts that have been identified in mouse models with emphasis on neuronal factors, the microbiome, immune cells and several hormones. We will also summarize the evidence for adipose tissue browning in humans including some experimental pharmacologic approaches.
\end{abstract}

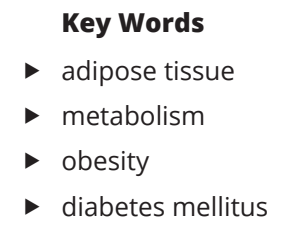

Journal of Endocrinology (2019) 241, R97-R109

\section{Adipose tissue browning and whitening}

A hallmark feature of adipose tissue browning is the induction of thermogenically active adipocytes in white fat depots. These adipocytes are often referred to as beige or brite (brown in white) cells and express high amounts of the key thermogenic factor uncoupling protein 1 (UCP1). UCP1 is located in the inner mitochondrial membrane and uncouples the proton motive force from oxidative phosphorylation leading to the dissipation of the energy as heat (Cannon \& Nedergaard 2004). Beige cells are inducible and possess characteristics of both, white and brown fat cells. The number of beige adipocytes increases substantially in mice in response to certain environmental, genetic or pharmacological stimuli (Kiefer 2016, Jankovic et al. 2017, Vargas-Castillo et al. 2017). One of the most potent physiologic inducers of adipose tissue browning is chronic cold exposure. Low temperatures are sensed by the skin and central signals result in the release of the neurotransmitter norepinephrine via sympathetic neurons (Cannon \& Nedergaard 2004). Through the activation of $\beta$-adrenergic receptors (predominantly subtype $\beta 3$ ) and downstream cyclic adenosine monophosphate signaling, a thermogenic gene program is turned on that defines a BAT-like molecular phenotype (Himms-Hagen et al. 1994, Rosell et al. 2014).

The appearance of newly formed beige adipocytes within white fat raises the question of where these cells 
come from. Two general concepts have been proposed: one is the precursor model which suggests that these beige cells are derived from distinct progenitor cells upon certain stimuli such as cold exposure or $\beta$-adrenergic stimulation. The other concept is the transdifferentiation model or more precisely the interconversion model because it proposes that mature white adipocytes can convert into beige adipocytes when appropriately challenged. There is high-quality evidence from elegant lineage tracing studies for both theories (Barbatelli et al. 2010, Lee et al. 2012, 2015, Rosenwald et al. 2013, Wang et al. 2013, Kiefer 2016). It is possible that additional factors such as the genetic background, the environment or fat depot-specific differences contribute to the decision how beige cells are ultimately formed.

Recently, a new hallmark of beige adipocytes has been identified using reporter mouse models that allow to tag white, beige and brown adipocytes. Warm temperatures confer a white fat program in both, beige and brown adipocytes, a process coined 'whitening'. However, only beige adipocytes undergo temperature-dependent chromatin reprogramming from brown toward white, while retaining an epigenomic memory of prior cold exposure. In other words, beige cells remember when they have previously been exposed to cold and can therefore quickly reboot their thermogenic machinery when re-challenged. These findings also emphasize the great molecular and metabolic plasticity of beige adipocytes and illustrate why adipose tissue browning has been linked to a lean phenotype and improved energy metabolism (Roh et al. 2018).

\section{Neuronal control of WAT beiging}

WAT is innervated by sympathetic noradrenergic nerve fibers with various innervation densities depending on the anatomical location (Youngstrom \& Bartness 1995). WAT denervation leads to an increased fat pad mass and fat cell number due to impaired centrally regulated lipolysis (Youngstrom \& Bartness 1998). Correspondingly, cold acclimation leads to increased tyrosine hydroxylasepositive nerve fibers indicative of higher innervation density and a higher fraction which is paralleled by the emergence of beige adipocytes in different WAT depots (Murano et al. 2009). Using retrograde neuronal viral tracing it has been demonstrated that BAT and WAT share both, common und distinct central neuronal projections, suggesting coordinated sympathetic nervous system control of BAT thermoregulation and beige cell recruitment (Nguyen et al. 2017).
A central regulator of BAT thermogenesis and WAT browning is hypothalamic AMP-activated protein kinase (AMPK). Activated by low intracellular energy stores, AMPK reduces ATP-consuming and promotes ATP-producing processes. Inactivation of AMPK in the ventromedial hypothalamus (VMH) increases sympathetic output to BAT and WAT which conveys BAT activation and WAT browning (Lopez et al. 2016). Several hormonal regulators of adipocyte browning act through AMPK. Central administration of liraglutide, a glucagonlike peptide 1 receptor agonist, thyroid hormones and estradiol increase thermogenesis through suppression of AMPK in the VMH (Lopez et al. 2010, Beiroa et al. 2014, Martinez De Morentin et al. 2014, Martinez-Sanchez et al. $2017 a, b)$. While the liraglutide and thyroid hormones enhance both BAT function and WAT browning, estradiol only affected BAT thermogenesis (Beiroa et al. 2014, Martinez De Morentin et al. 2014, Martinez-Sanchez et al. 2017a). Deletion of the AMPK subunit AMPK 1 in steroidogenic factor 1 neurons in the VMH promotes a thermogenic program in BAT and WAT and thus could represent a potential treatment target for metabolic disease (Martinez-Sanchez et al. 2017b, Seoane-Collazo et al. 2018). Whereas decreasing hypothalamic AMPK activity seems to confer some metabolic benefits, the loss of adipocyte AMPK exacerbates insulin resistance and hepatic steatosis through impaired brown and beige fat function (Mottillo et al. 2016). Potential therapies targeting AMPK activity must thus be tissue specific in order to maximize metabolic benefit.

Hypothalamic endoplasmic reticulum stress is an important contributing factor leading to diminished thermogenesis and WAT browning which is induced, e.g. through ceramide-mediated lipotoxicity and alleviated through the chaperone GRP78/BiP (glucose-regulated protein $78 \mathrm{kDa} /$ binding immunoglobulin protein) (Contreras et al. 2014, 2017a). The mechanisms by which estradiol and thyroid hormones positively regulate energy balance also include the suppression of VMH endoplasmic reticulum (Martinez-Sanchez et al. 2017b, GonzalezGarcia et al. 2018).

The arcuate nucleus is another important hypothalamic structure controlling adipose tissue thermogenesis. It harbors orexigenic neuropeptide $\mathrm{Y}$ (NPY)/agouti-related protein (AgRP) neurons which are counteracted by anorexigenic pro-opiomelanocortin (POMC) and cocaine- and amphetamine-regulated transcript (CART) neurons. In addition to their established role in feeding control, arcuate nucleus neurons are involved in the central regulation of energy expenditure 
through their canonical modulators such as the prothermogenic leptin or the anti-thermogenic ghrelin (Dodd et al. 2015, Contreras et al. 2017b, Wu et al. 2017). POMC neuron-specific deletion of inositol-requiring enzyme $\alpha$, a regulator of the unfolded protein response, leads to impaired BAT thermogenesis and reduced WAT browning due to increased hypothalamic endoplasmic reticulum stress and leptin resistance (Yao et al. 2017). O-linked $\beta$-N-acetylglucosamine (O-GlcNAc) signaling in AgRP neurons suppresses thermogenesis and conserves energy in response to fasting, whereas inactivation of the modifying enzyme O-GlcNAc transferase induces WAT browning and protects against obesity and insulin resistance (Ruan et al. 2014).

Activation of hypothalamic guanylyl cyclase 2C through the intestinal hormone uroguanylin has been shown to regulate feeding and to induce BAT thermogenesis as well as WAT browning in mice, in part possibly through hypothalamic POMC signaling (Valentino et al. 2011, Folgueira et al. 2016). However, some studies question the metabolic relevance of this new proposed gut-brain axis (Begg et al. 2014, Fernandez-Cachon et al. 2018).

\section{Beiging and the gut microbiome}

Among the different factors that have been linked to adipose tissue browning, the gut microbiota deserves particular attention. Previously, cold exposure has been shown to alter the microbial composition in the gut and transfer of microbiota from cold-adapted mice into germ-free mice induced WAT browning in the recipients with consecutively improved cold tolerance and insulin sensitivity (Chevalier et al. 2015, Zietak et al. 2016). More recently intermittent fasting has been demonstrated to have similar effects. Every other day fasting (EODF) compared to ad libitum feeding resulted in a shift in the gut microbiota composition, selectively stimulated beige fat development within WAT and dramatically attenuated obesity, insulin resistance and hepatic steatosis in mice. Importantly, also the transplantation of microbiota from EODF-treated mice to germ-free mice activated beiging and improved glucose metabolism, whereas microbiotadepleted mice were resistant to EODF-induced adipose browning. The underlying mechanism seems to involve increased intestinal lactate production by the newly formed microbiome after intermittent fasting (Li et al. 2017). Lactate production was also increased in response to cold exposure and lactate has previously been established as a potent inducer of thermogenic gene expression in mouse and human adipocytes (Carrière et al. 2014). Recently, short-term caloric restriction was demonstrated in mice to confer a very similar phenotype as intermittent fasting. Thirty days of $40 \%$ caloric restriction significantly altered the gut microbial composition and promoted adipose tissue browning. Mechanistically, these effects were linked to lower expression of the key bacterial enzymes necessary for the lipid A biosynthesis, a critical lipopolysaccharide (LPS)-building component. Decreased LPS production was associated with anti-inflammatory M2 macrophage polarization and eosinophil infiltration in WAT (Fabbiano et al. 2018). Both cell types have previously been shown to contribute to the thermogenic reprograming of WAT (Qiu et al. 2014). Together, these findings not only established a microbiota-fat signaling axis but linked innate immune responses with adipose tissue browning.

\section{Immune cells and thermogenic programming}

First evidence for a direct contribution of immune cells toward adaptive thermogenesis came in 2011 when it was reported that cold exposure rapidly promoted interleukin 4 (IL4)-dependent alternative activation of adipose tissue macrophages. It was postulated that these M2 type macrophages release catecholamines to induce thermogenic gene expression in BAT and lipolysis in WAT (Nguyen et al. 2011). However, these findings have been contradicted by others showing that specific deletion of the rate-limiting enzyme of catecholamine synthesis, tyrosine hydroxylase, in hematopoietic cells does not affect adipose browning or cold tolerance in mice. In addition, bone marrow-derived macrophages did not release norepinephrine in response to stimulation with IL4, and conditioned media from IL4-stimulated macrophages failed to induce the expression of thermogenic genes in isolated adipocytes (Fischer et al. 2017). The controversy of this topic is further highlighted by a recent report showing that a newly identified macrophage population - so called sympathetic neuron-associated macrophages (SAMs) - import and degrade norepinephrine via the transporter solute carrier family 6 member 2 and the degradation enzyme monoamine oxidase A, that are not present in other adipose tissue macrophages. They also demonstrated that SAM-mediated clearance of extracellular norepinephrine has detrimental effects on adipose tissue browning, thermogenesis and obesity (Pirzgalska et al. 2017).

Eosinophils are another critical immune cell population involved in adipose tissue thermogenesis. Genetic loss of 
eosinophils or IL4/13 signaling impaired cold-induced biogenesis of beige fat through lack of alternative activation of M2 macrophages (Qiu et al. 2014). Another study identified the circulating muscle-derived factor meteorin-like that was induced in response to exercise and stimulated WAT browning due to eosinophil-dependent type 2 cytokine production and anti-inflammatory macrophage activation (Rao et al. 2014).

\section{Exercise and browning}

Accumulating evidence in rodents suggests that exercise contributes to adipose browning mainly through hormonal factors including myocyte-secreted molecules called myokines. The first myokine that has been linked to WAT browning was irisin, a cleavage product of the membrane-bound protein fibronectin type III domaincontaining protein 5 (FNDC5). Many of the beneficial metabolic effects of exercise on muscle are mediated by PPAR $\gamma$ coactivator-1 $\alpha$ (PGC1A). Transgenic expression of PGC1A in muscle stimulated FNDC5 expression and induced WAT browning. Also, treatment of primary adipocytes with recombinant irisin promoted thermogenic gene expression (Bostrom et al. 2012). Even though elevated circulating irisin levels were reported in exercised mice, results in humans are much more controversial (Crujeiras et al. 2015). Several human studies failed to show an increase in systemic irisin concentrations after acute or chronic endurance training despite enhanced PGC1A expression in muscle (Hecksteden et al. 2013, Moraes et al. 2013, Kurdiova et al. 2014, Norheim et al. 2014, Qiu et al. 2015).

Another exercise-induced circulating factor secreted from skeletal muscle is IL6. Accumulating evidence implicates IL6 in exercise-dependent WAT browning. Indeed, IL6-deficient mice were resistant to exerciseinduced thermogenic gene expression in white fat (Knudsen et al. 2014). Both, in vivo and in vitro treatment with IL6 stimulated UCP1 expression in white adipocytes (Wan et al. 2012, Knudsen et al. 2014). However, skeletal muscle does not seem to be the only source of exerciseinduced IL6 production, given that muscle-specific IL6-knockout mice displayed increased IL6 levels in response to exercise (Gudiksen et al. 2016).

Although fibroblast growth factor 21 (FGF21) is not a classic myokine (it is mainly secreted by the liver), it is also increased after acute and long-term exercise (Staiger et al. 2017). FGF21 has become a focus of clinical trials for obesity and diabetes because it has many beneficial effects on metabolism including increased glucose uptake, improved insulin sensitivity and weight reduction (Gaich et al. 2013, Talukdar et al. 2016). Some of these FGF21 actions may be mediated, at least in part, by stimulating fatty acid oxidation and energy dissipation through browning of adipocytes (Xu et al. 2009, Fisher et al. 2012, Schlein et al. 2016). Mice deficient in FGF21 displayed an impaired ability to adapt to chronic cold exposure with diminished browning of WAT (Fisher et al. 2012). Administration of FGF21 lowered plasma triglycerides in mice through reduced hepatic very low-density lipoprotein secretion and increased lipoprotein disposal in adipose tissue (Schlein et al. 2016). FGF21 and PRDM16 have been reported to compensate for the reduced sympathetic response to cold exposure in a tyrosine hydroxylase haplodeficient mouse model suggesting a mechanism independent of the classic adrenergic pathway (Vazquez et al. 2018). In humans, circulating FGF21 correlated with brown fat activity determined by FDG uptake in PET/CT studies and in human brown adipocytes FGF21 and FNDC5 had additive effects on norepinephrine-stimulated thermogenesis (Lee et al. 2014a, Hanssen et al. 2015a).

\section{Endogenous modulators of WAT browning}

Other hormones with significant browning potential are parathyroid hormone (PTH) and PTH-related peptide (PTHRP). In a mouse model of kidney failure, secondary hyperparathyroidism promoted muscle wasting and cachexia through WAT browning (Kir et al. 2016). A similar phenotype was observed in a murine lung carcinoma model with excess PTHRP production (Kir et al. 2014). These effects were abolished in adipose tissue PTH receptorknockout mice arguing for a fat-specific PTH receptor signaling pathway (Kir et al. 2016). These findings also suggested potential detrimental effects of increased energy wasting through adipose tissue browning, particularly in diseases associated with a catabolic state. Extending previous findings of PTH action in mouse WAT, our lab recently found that PTH stimulation in human primary adipocytes isolated from subcutaneous fat triggered a thermogenic program with increased UCP1 expression and enhanced cellular respiration (Hedesan et al. 2018). This suggests a previously unknown parathyroid-adipose crosstalk in humans and raises important questions about the regulation of energy expenditure in medical conditions associated with high PTH or PTHRP levels. The physiological connection between increased PTH receptor signaling and catabolic states is unclear; 
however, it is possible that PTH and PTHRP oversecretion trigger maladaptive processes that result in enhanced lipolytic activity and energy wasting.

There is also accumulating evidence for a crosstalk between heart and adipose tissue. Heart-derived hormones such as the natriuretic peptides can control fat function including non-shivering thermogenesis and fatty acid oxidation (Sengenes et al. 2000, 2003, Bordicchia et al. 2012). For instance, infusion of the brain natriuretic peptide, which is usually elevated in heart failure patients, caused increased UCP1 expression in subcutaneous fat and enhanced energy expenditure in mice. This effect was mainly mediated by natriuretic peptide receptors through the activation of p38 MAPK (Bordicchia et al. 2012). Recently, cardiotrophin-1, a heart-derived cytokine, was also found to improve glucose and lipid metabolism, with enhanced mitochondrial biogenesis and browning of WAT (Moreno-Aliaga et al. 2011).

Bile acids are another group of important signaling molecules with potent action within adipose tissue. Most of the metabolic effects of bile acids are mediated through the nuclear receptor farnesoid X receptor (FXR) and the G protein-coupled bile acid receptor TGR5 (Li \& Chiang 2015). In mice, cold exposure induced hepatic conversion of cholesterol to bile acids via the alternative bile acid synthesis pathway that involves cytochrome P450, family 7, subfamily b and polypeptide 1 (CYP7B1). As a result, plasma levels and fecal excretion of bile acids were increased in response to cold, whereas this effect was blunted in CYP7B1-deficient mice. CYP7B1 deficiency also mitigated cold-induced thermogenic gene expression in WAT and BAT with reduced core body temperatures (Worthmann et al. 2017). Selective activation of intestinal FXR induced fibroblast growth factor 15, leading to altered bile acid composition with enhanced WAT thermogenesis and protection against diet-induced weight gain (Fang et al. 2015). In addition, pharmacologic administration of chenodeoxycholic acid promoted thermogenic gene expression and weight loss in mice and stimulated BAT activity and energy expenditure in humans (Teodoro et al. 2014, Broeders et al. 2015).

Recent data suggest that BAT serves also as a secretory organ and thereby contributes to its own activation and/or browning of WAT. The chemokine CXCL14 has recently been identified as a novel BAT-derived adipokine that is involved in the recruitment of alternatively activated macrophages, WAT browning and improved glucose homeostasis in obese mice. Impairment of type 2 cytokine signaling, as seen in Stat6-deficient mice, blunted the action of CXCL14 (Cereijo et al. 2018). These findings suggested again a potential crosstalk between immune cells and adipocytes, controlling the thermogenic remodeling of adipose tissue.

Using a lipidomic approach, Lynes et al. identified 12,13-dihydroxy-9Z-octadecenoic acid (12,13-diHOME) as a cold-induced lipokine in humans which correlates with BAT activity and a favorable metabolic risk profile. Brown adipocytes have been identified as the primary source of cold-induced circulating 12,13-diHOME in mice. 12,13-diHOME increases fatty acid uptake into brown/beige adipocytes by increasing the expression of the fatty acid transporters FATP1 and CD36 within the cell membrane which promotes triglyceride clearance and thus facilitates a thermogenic program (Lynes et al. 2017).

\section{Adipocyte browning in humans}

Since the discovery of functional BAT in human adults through the advent of the widespread use of ${ }^{18} \mathrm{~F}-\mathrm{FDG}$ PET imaging (Nedergaard et al. 2007), almost a decade of research has been committed toward the importance of BAT for human energy metabolism. In several crosssectional clinical studies using cold exposure to activate BAT, the presence of BAT ${ }^{18} \mathrm{~F}-\mathrm{FDG}$ uptake was associated with reduced adiposity, younger age and a more favorable metabolic profile (Saito et al. 2009a, b, Van Marken Lichtenbelt et al. 2009, Virtanen et al. 2009, Yoneshiro et al. 2011b, Matsushita et al. 2014). Biopsy studies confirmed that these ${ }^{18}$ F-FDG-positive fat depots contained multilocular UCP1-expressing brown adipocytes (Cypess et al. 2009, Zingaretti et al. 2009). Active BAT depots were mainly discernable in cervical, supraclavicular as well as axillary and sometimes in mediastinal, paraspinal and abdominal fat depots (Leitner et al. 2017). BAT activity was positively associated with the cold-induced increase in non-shivering thermogenesis (Yoneshiro et al. 2011a, Chen et al. 2013). However, in a larger representative cohort in a healthy Japanese population only $48 \%$ showed detectable cold-induced BAT activity, all measured during winter when BAT ${ }^{18} \mathrm{~F}-\mathrm{FDG}$ uptake was highest (Saito et al. 2009b, Matsushita et al. 2014, Bahler et al. 2016).

The idea of positively influencing energy balance in obesity by increasing BAT thermogenesis is hampered by reduced BAT activity in obesity (Van Marken Lichtenbelt et al. 2009, Matsushita et al. 2014). Even in subjects with high BAT volume, the overall small BAT-specific increase in daily energy expenditure under cold stimulation 
accounts only for a small proportion of non-shivering thermogenesis (Muzik et al. 2013, Din et al. 2016). Alternative therapeutic approaches could therefore include the browning of large classical WAT depots such as the abdominal subcutaneous fat and the visceral fat in order to achieve a larger volume of thermogenically active adipose tissue. Numerous cold exposure studies in mice found that that subcutaneous adipose tissue (SAT) depots are more susceptible to browning than the metabolically unfavorable visceral fat (Seale et al. 2011, Van Der Stelt et al. 2017). In general, very little is known about the anatomical differences in the browning susceptibility of human WAT. However, one study found that in obese subjects, omental fat expressed higher transcript levels of browning markers and genes involved in mitochondrogenesis compared to abdominal subcutaneous fat (Zuriaga et al. 2017). Visceral adipose tissue (VAT) has consistently been associated with an adverse cardio-metabolic risk profile (Fox et al. 2007, Liu et al. 2010, Neeland et al. 2013, Abraham et al. 2015). Excess VAT has also been implicated in the pathogenesis of non-alcoholic fatty liver disease through the drainage of pro-inflammatory adipokines as well as lipotoxicity mediated by free fatty acids in the portal circulation (Baranova et al. 2007, Verrijken et al. 2010, Eguchi et al. 2011, Wree et al. 2011). Hence, the combustion of excess fatty acids and decreasing the inflammatory state through the browning of VAT could provide manifold benefits in the prevention of metabolic disease. Based on numerous animal studies it is possible that browning of both SAT and VAT may have beneficial effects on global energy metabolism.

\section{Is human WAT susceptible to browning?}

There is also some evidence that human SAT can undergo browning at least under very extreme conditions. In a study in intensive care patients the authors found that severe burn injuries led to an increase of UCP1-positive beige cells within the subcutaneous fat with a maximum several weeks after the injury. This was linked to the severe adrenergic stress and the prolonged elevation of norepinephrine levels seen after such burn injuries (Sidossis et al. 2015). Endogenous catecholamine excess can also trigger browning of the visceral fat compartment as observed in a study in pheochromocytoma patients. Whereas 50\% of pheochromocytoma patients undergoing cholecystectomy had UCP1-positive brown adipocytes in the greater omentum, none of the control patients had any signs of WAT browning (Frontini et al. 2013). Another study in pheochromocytoma patients, however, found brown/beige adipocytes only in periadrenal but neither omental nor subcutaneous fat (Vergnes et al. 2016). WAT browning also seems to underlie seasonal variations since the expression of thermogenic marker genes in SAT was increased during winter compared to biopsies obtained during summer. In the same study, the application of an ice pack to the skin of one thigh for $30 \mathrm{~min}$ resulted in a 1.9-fold and 2.7-fold increase in UCP1 and PGC1A mRNA levels, respectively. This effect was not present during winter which was attributed to the higher baseline levels.

In primary adipocyte cell cultures derived from femoral SAT, the direct exposure of cells to $16^{\circ} \mathrm{C}$ for $30 \mathrm{~min}$ led to a delayed increase in thermogenic gene expression which became noticeable only 4 and $24 \mathrm{~h}$ after recovery from the cold stimulus (Kern et al. 2014). Interestingly, in murine adipocytes, this thermo-sensory capacity was only observed in WAT and beige adipocytes but not in BAT (Ye et al. 2013).

\section{Interventional approaches targeting BAT activity and WAT browning}

Cold exposure studies of variable duration have repeatedly demonstrated that bone fide BAT can be successfully activated and recruited in humans through cold stress (van der Lans et al. 2013, Yoneshiro et al. 2013, Blondin et al. 2014, Lee et al. 2014b, Hanssen et al. 2015b, 2016). However, none of the studies found abdominal WAT browning using abdominal subcutaneous biopsies of SAT/VAT or ${ }^{18} \mathrm{~F}-\mathrm{FDG}$ PET scans (van der Lans et al. 2013, Hanssen et al. 2015b, 2016) suggesting that moderate cold exposure may not be sufficient to promote WAT browning in humans.

$\beta$-adrenergic receptor agonists are among the most widely studied pharmacological agents that induce BAT function and browning of WAT. Drugs highly selective for human $\beta_{3}$ adrenergic receptors (AR) with a good oral bioavailability were developed but they failed in the clinic due to their $\beta_{1}$ - and $\beta_{2}$-AR-mediated cardiovascular effects in humans (Arch 2011). However, recently the selective $\beta_{3}$-agonist mirabegron, previously approved for the treatment of overactive bladder, was shown to increase BAT activity and energy expenditure in humans without causing severe cardiovascular side effects. After a single dose of $200 \mathrm{mg}$, BAT ${ }^{18}$ F-FDG uptake and resting https://joe.bioscientifica.com

https://doi.org/10.1530/JOE-18-0598
(C) 2019 Society for Endocrinology Published by Bioscientifica Ltd. Printed in Great Britain 
metabolic rate but also blood pressure were increased in healthy young lean men (Cypess et al. 2015). Daily intake of $50 \mathrm{mg}$ mirabegron for 10 weeks induced the beiging of abdominal SAT in obese participants, demonstrated by increased protein content of thermogenic markers such as UCP1 (Finlin et al. 2018). Long-term studies in obese and insulin-resistant individuals are warranted to investigate the effectiveness and cardiovascular safety of mirabegron treatment to induce weight loss and improvements in metabolic health.

Another pharmacological approach involved the phosphodiesterase type-5 inhibitor sildenafil which is marketed for the treatment of erectile dysfunction. It was recently tested in a double-blind placebo-controlled trial after animal studies had demonstrated promising effects of sildenafil as a browning agent. Indeed a 7-day treatment with $100 \mathrm{mg}$ sildenafil daily resulted in the induction of UCP1-expressing beige cells within the SAT. This was accompanied by an increase in the resting metabolic rate and elevated catecholamine and cGMP concentrations. However, this study does not allow to draw any conclusions about the effect of sildenafil on classical human BAT because only three participants underwent ${ }^{18} \mathrm{~F}-\mathrm{FDG}$ PET/CT scans (Li et al. 2018). Interestingly, previous preclinical work had already suggested that cGMP and consecutive mTOR activation are also mechanistically involved in the induction of a thermogenic gene program (Liu et al. 2018).

Inhibitors of the sodium-glucose cotransporter 2 (SGLT2) are potent antidiabetic drugs with additional body weight-lowering effects due to increased urinary glucose excretion. However, a recent study in mice identified another potential mechanism that may contribute toward body weight loss seen with SGLT2 inhibition. Oral administration of empagliflozin in mice on a high-fat diet reduced M1-polarized macrophage accumulation in adipose tissue while favoring an anti-inflammatory M2 macrophage phenotype. As a consequence, WAT browning and fat utilization were increased which attenuated weight gain and insulin resistance (Xu et al. 2017).

The anticancer drug imatinib was found to block cyclin-dependent kinase 5-mediated peroxisome proliferator-activated receptor $\gamma$ (PPARG) phosphorylation in obese mice while acting as a non-classical PPARG ligand. Similar to the classical PPARG ligands thiazolidinediones, imatinib improved insulin sensitivity and hepatic steatosis and increased energy expenditure through WAT browning (Choi et al. 2016).
Increasing whole body nitric oxide availability through oral L-arginine supplementation has the potential to promote adipocyte thermogenesis through increased mitochondrogenesis in mice (Nisoli et al. 2003, 2004). A recent study in humans, however, did not show any effect of L-arginine on BAT activity or energy expenditure while suggesting an improvement in cold-induced glucose oxidation (Boon et al. 2019).

Tissue grafting procedures could represent an alternative strategy to conventional pharmacological approaches due to the lack of potential systemic side effects. An initial study in mice revealed that transplantation of subcutaneous fat into the visceral cavity of the host mice exerted beneficial metabolic effects while transplantation of epididymal fat into any of the two depots did not. A salutary secretory profile of subcutaneous fat was suggested to contribute to its beneficial effects (Tran et al. 2008). Transplantation of BAT into the visceral cavity of mice has also been shown to improve glucose metabolism and body composition dependent on the presence of BAT-derived interleukin 6 (Stanford et al. 2013). We recently reported a concept that involved autologous beige fat transplantation. First, murine SAT fragments were exposed to a single-step browning procedure using a distinct culture medium. After 3 weeks of ex vivo culture, the fragments were re-implanted and explanted again 8 weeks later. Not only was the auto-transplant well integrated and vascularized, those tissues that were ex vivo treated with browning media showed sustained UCP1 expression, whereas the tissues cultured in control media retained a WAT-like appearance. Most importantly, this protocol was also successfully applied in human fat. By incubating small fragments from abdominoplastic surgeries with browning media for 2-week conversion of WAT into UCP1-expressing multilocular beige fat was achieved (Blumenfeld et al. 2018).

\section{Conclusion and future outlook}

Targeting BAT and browning of WAT have emerged as potential strategies to treat obesity and its related metabolic disorders. Particularly, the transformation of WAT into a thermogenically active fat depot holds great promise as a therapeutic intervention given the excess amount of white fat in obese conditions. Increasing research efforts have identified a large number of molecular pathways controlling the reprogramming of white into beige adipocytes. 


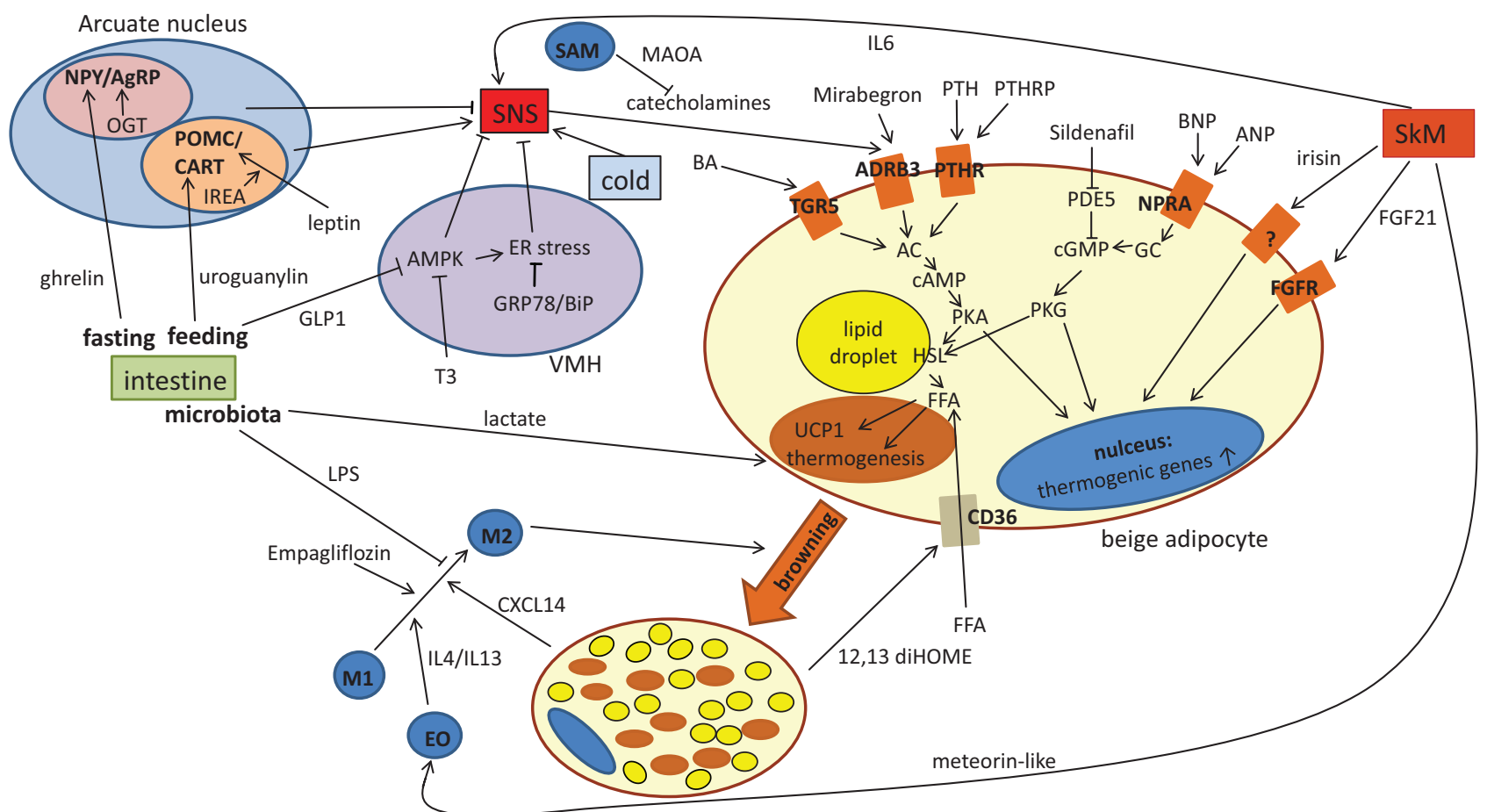

\section{Figure 1}

Summary of proposed mechanisms involved in the browning of white adipose tissue. 12,13 diHOME, 12,13-dihydroxy-9Z-octadecenoic acid; AgRP, agouti-related protein; AMPK, adenosine monophosphate-activated protein kinase; ANP, atrial natriuretic peptide; AC, adenylate cyclase; ADRB3, $\beta 3$-adrenergic receptor; BA, bile acid; BNP, B-type natriuretic peptide; CAMP, cyclic adenosine monophosphate; CART, cocaine and amphetamineregulated transcript; CD36, cluster of differentiation 36; cGMP, cyclic guanosine monophosphate; CXCL14, C-X-C Motif Chemokine Ligand 14; EO, eosinophil; ER, endoplasmic reticulum; FFA, free fatty acid; FGF21, fibroblast growth factor 21; FGFR, fibroblast growth factor receptor; GC, guanylyl cyclase; GLP1, glucagon-like peptide 1; GRP78/BiP, 78-kDa glucose-regulated protein/binding immunoglobulin protein; HSL, hormone-sensitive lipase; IL, interleukin; IRE1A, inositol-requiring enzyme 1 $\alpha$; LPS, lipopolysaccharide; M1, M1 macrophage; M2, M2 macrophage; MAOA, monoamine oxidase A; NPY, neuropeptide Y; OGT, O-linked N-acetylglucosaminyltransferase; PDE5, phosphodiesterase type 5; PKA, protein kinase A; PKG: protein kinase G; POMC, pro-opiomelanocortin; PTH, parathyroid hormone; PTHR, parathyroid hormone receptor; PTHRP, parathyroid hormone-related peptide; SAM, sympathetic neuron-associated macrophage; SkM, skeletal muscle; SNS, sympathetic nervous system; T3, triiodothyronine; TGR5, G protein-coupled bile acid receptor; UCP1, uncoupling protein 1; VMH, ventro-medial hypothalamus.

These pathways as discussed in this review are summarized in Figure 1. In addition, accumulating evidence suggests that browning of WAT can also occur in humans either under extreme medical conditions such as severe adrenergic stress or in response to some pharmacological stimuli. However, it remains to be resolved whether WAT browning in humans can be harnessed therapeutically to increase energy expenditure and reduce body fat mass. Additional research is needed to identify the distinct cell populations in human fat depots that can give rise to thermogenically active beige fat cells. Another area of investigation concerns the development of novel radioligands that can be used as alternative tracers to detect and quantify BAT activity and potentially beige fat within classic WAT depots. Together, all these research efforts will improve our understanding of BAT function and WAT browning with the ultimate goal of developing new therapeutics for the treatment of obesity and related sequelae.

\section{Declaration of interest}

The authors declare that there is no conflict of interest that could be perceived as prejudicing the impartiality of this review.

\section{Funding}

This work was supported by the Vienna Science and Technology Fund (WWTF) LS12-059 and the Austrian Science Fund (FWF) P 27391-B26 (both to F W K).

\section{References}

Abraham TM, Pedley A, Massaro JM, Hoffmann U \& Fox CS 2015 Association between visceral and subcutaneous adipose depots and incident cardiovascular disease risk factors. Circulation 132 1639-1647. (https://doi.org/10.1161/CIRCULATIONAHA.114.015000) Arch JRS 2011 Challenges in $\beta$ (3)-adrenoceptor agonist drug development. Therapeutic Advances in Endocrinology and Metabolism 2 59-64. (https://doi.org/10.1177/2042018811398517) 
Bahler L, Deelen JW, Hoekstra JB, Holleman F \& Verberne HJ 2016 Seasonal influence on stimulated BAT activity in prospective trials: a retrospective analysis of BAT visualized on 18F-FDG PET-CTs and 123I-mIBG SPECT-CTs. Journal of Applied Physiology 120 1418-1423. (https://doi.org/10.1152/japplphysiol.00008.2016)

Baranova A, Schlauch K, Elariny H, Jarrar M, Bennett C, Nugent C, Gowder SJ, Younoszai Z, Collantes R, Chandhoke V, et al. 2007 Gene expression patterns in hepatic tissue and visceral adipose tissue of patients with non-alcoholic fatty liver disease. Obesity Surgery 17 1111-1118. (https://doi.org/10.1007/s11695-007-9187-y)

Barbatelli G, Murano I, Madsen L, Hao Q, Jimenez M, Kristiansen K, Giacobino JP, De Matteis R \& Cinti S 2010 The emergence of coldinduced brown adipocytes in mouse white fat depots is determined predominantly by white to brown adipocyte transdifferentiation. American Journal of Physiology: Endocrinology and Metabolism 298 E1244-E1253. (https://doi.org/10.1152/ajpendo.00600.2009)

Begg DP, Steinbrecher KA, Mul JD, Chambers AP, Kohli R, Haller A, Cohen MB, Woods SC \& Seeley RJ 2014 Effect of guanylate cyclase-C activity on energy and glucose homeostasis. Diabetes 63 3798-3804. (https://doi.org/10.2337/db14-0160)

Beiroa D, Imbernon M, Gallego R, Senra A, Herranz D, Villarroya F, Serrano M, Ferno J, Salvador J, Escalada J, et al. 2014 GLP-1 agonism stimulates brown adipose tissue thermogenesis and browning through hypothalamic AMPK. Diabetes 63 3346-3358. (https://doi. org/10.2337/db14-0302)

Blondin DP, Labbé SM, Tingelstad HC, Noll C, Kunach M, Phoenix S, Guérin B, Turcotte EE, Carpentier AC, Richard D, et al. 2014 Increased brown adipose tissue oxidative capacity in cold-acclimated humans. Journal of Clinical Endocrinology and Metabolism 99 E438-E446. (https://doi.org/10.1210/jc.2013-3901)

Blumenfeld NR, Kang HJ, Fenzl A, Song Z, Chung JJ, Singh R, Johnson R, Karakecili A, Feranil JB, Rossen NS, et al. 2018 A direct tissue-grafting approach to increasing endogenous brown fat. Scientific Reports $\mathbf{8}$ 7957. (https://doi.org/10.1038/s41598-018-25866-y)

Boon MR, Hanssen MJW, Brans B, Hulsman CJM, Hoeks J, Nahon KJ, Bakker C, Van Klinken JB, Havekes B, Schaart G, et al. 2019 Effect of L-arginine on energy metabolism, skeletal muscle and brown adipose tissue in South Asian and Europid prediabetic men: a randomised double-blinded crossover study. Diabetologia 62 112-122. (https://doi. org/10.1007/s00125-018-4752-6)

Bordicchia M, Liu D, Amri EZ, Ailhaud G, Dessì-Fulgheri P, Zhang C, Takahashi N, Sarzani R \& Collins S 2012 Cardiac natriuretic peptides act via p38 MAPK to induce the brown fat thermogenic program in mouse and human adipocytes. Journal of Clinical Investigation 122 1022-1036. (https://doi.org/10.1172/JCI59701)

Bostrom P, Wu J, Jedrychowski MP, Korde A, Ye L, Lo JC, Rasbach KA, Bostrom EA, Choi JH, Long JZ, et al. 2012 A PGC1-alpha-dependent myokine that drives brown-fat-like development of white fat and thermogenesis. Nature $\mathbf{4 8 1}$ 463-468. (https://doi.org/10.1038/ nature10777)

Broeders EPM, Nascimento EBM, Havekes B, Brans B, Roumans KHM, Tailleux A, Schaart G, Kouach M, Charton J, Deprez B, et al. 2015 The bile acid chenodeoxycholic acid increases human brown adipose tissue activity. Cell Metabolism 22 418-426. (https://doi.org/10.1016/j. cmet.2015.07.002)

Cannon B \& Nedergaard J 2004 Brown adipose tissue: function and physiological significance. Physiological Reviews 84 277-359. (https:// doi.org/10.1152/physrev.00015.2003)

Carrière A, Jeanson Y, Berger-Müller S, André M, Chenouard V, Arnaud E, Barreau C, Walther R, Galinier A, Wdziekonski B, et al. 2014 Browning of white adipose cells by intermediate metabolites: an adaptive mechanism to alleviate redox pressure. Diabetes 63 3253-3265. (https://doi.org/10.2337/db13-1885)

Cereijo R, Gavalda-Navarro A, Cairo M, Quesada-Lopez T, Villarroya J, Moron-Ros S, Sanchez-Infantes D, Peyrou M, Iglesias R, Mampel T, et al. 2018 CXCL14, a brown adipokine that mediates brown-fat-to- macrophage communication in thermogenic adaptation. Cell Metabolism 28 750.e6-763.e6. (https://doi.org/10.1016/j.cmet.2018.07.015)

Chen KY, Brychta RJ, Linderman JD, Smith S, Courville A, Dieckmann W, Herscovitch P, Millo CM, Remaley A, Lee P, et al. 2013 Brown fat activation mediates cold-induced thermogenesis in adult humans in response to a mild decrease in ambient temperature. Journal of Clinical Endocrinology and Metabolism 98 E1218-E1223. (https://doi. org/10.1210/jc.2012-4213)

Chevalier C, Stojanovic O, Colin DJ, Suarez-Zamorano N, Tarallo V, Veyrat-Durebex C, Rigo D, Fabbiano S, Stevanovic A, Hagemann S, et al. 2015 Gut microbiota orchestrates energy homeostasis during cold. Cell 163 1360-1374. (https://doi.org/10.1016/j.cell.2015.11.004)

Choi SS, Kim ES, Jung JE, Marciano DP, Jo A, Koo JY, Choi SY, Yang YR, Jang HJ, Kim EK, et al. 2016 PPARgamma antagonist Gleevec improves insulin sensitivity and promotes the browning of white adipose tissue. Diabetes 65 829-839. (https://doi.org/10.2337/db15-1382)

Contreras C, Gonzalez-Garcia I, Martinez-Sanchez N, Seoane-Collazo P, Jacas J, Morgan DA, Serra D, Gallego R, Gonzalez F, Casals N, et al. 2014 Central ceramide-induced hypothalamic lipotoxicity and ER stress regulate energy balance. Cell Reports 9 366-377. (https://doi. org/10.1016/j.celrep.2014.08.057)

Contreras C, Gonzalez-Garcia I, Seoane-Collazo P, Martinez-Sanchez N, Linares-Pose L, Rial-Pensado E, Ferno J, Tena-Sempere M, Casals N, Dieguez C, et al. 2017a Reduction of hypothalamic endoplasmic reticulum stress activates browning of white fat and ameliorates obesity. Diabetes 66 87-99. (https://doi.org/10.2337/db15-1547)

Contreras C, Nogueiras R, Dieguez C, Rahmouni K \& Lopez M 2017 b Traveling from the hypothalamus to the adipose tissue: the thermogenic pathway. Redox Biology 12 854-863. (https://doi. org/10.1016/j.redox.2017.04.019)

Crujeiras AB, Pardo M \& Casanueva FF 2015 Irisin: 'fat' or artefact. Clinical Endocrinology 82 467-474. (https://doi.org/10.1111/ cen.12627)

Cypess AM, Lehman S, Williams G, Tal I, Rodman D, Goldfine AB, Kuo FC, Palmer EL, Tseng YH, Doria A, et al. 2009 Identification and importance of brown adipose tissue in adult humans. New England Journal of Medicine 360 1509-1517. (https://doi.org/10.1056/ NEJMoa0810780)

Cypess AM, Weiner LS, Roberts-Toler C, Franquet Elía E, Kessler SH, Kahn PA, English J, Chatman K, Trauger SA, Doria A, et al. 2015 Activation of human brown adipose tissue by a $\beta 3$-adrenergic receptor agonist. Cell Metabolism 21 33-38. (https://doi.org/10.1016/j. cmet.2014.12.009)

Din UM, Raiko J, Saari T, Kudomi N, Tolvanen T, Oikonen V, Teuho J, Sipilä HT, Savisto N, Parkkola R, et al. 2016 Human brown adipose tissue [(15)O]O2 PET imaging in the presence and absence of cold stimulus. European Journal of Nuclear Medicine and Molecular Imaging 43 1878-1886. (https://doi.org/10.1007/s00259-016-3364-y)

Dodd GT, Decherf S, Loh K, Simonds SE, Wiede F, Balland E, Merry TL, Munzberg H, Zhang ZY, Kahn BB, et al. 2015 Leptin and insulin act on POMC neurons to promote the browning of white fat. Cell $\mathbf{1 6 0}$ 88-104. (https://doi.org/10.1016/j.cell.2014.12.022)

Eguchi Y, Mizuta T, Sumida Y, Ishibashi E, Kitajima Y, Isoda H, Horie H, Tashiro T, Iwamoto E, Takahashi H, et al. 2011 The pathological role of visceral fat accumulation in steatosis, inflammation, and progression of nonalcoholic fatty liver disease. Journal of Gastroenterology 46 (Supplement 1) 70-78. (https://doi.org/10.1007/ s00535-010-0340-3)

Fabbiano S, Suarez-Zamorano N, Chevalier C, Lazarevic V, Kieser S, Rigo D, Leo S, Veyrat-Durebex C, Gaia N, Maresca M, et al. 2018 Functional gut microbiota remodeling contributes to the caloric restriction-induced metabolic improvements. Cell Metabolism 28907. e7-921.e7. (https://doi.org/10.1016/j.cmet.2018.08.005)

Fang S, Suh JM, Reilly SM, Yu E, Osborn O, Lackey D, Yoshihara E, Perino A, Jacinto S, Lukasheva Y, et al. 2015 Intestinal FXR agonism promotes adipose tissue browning and reduces obesity and insulin https://joe.bioscientifica.com

https://doi.org/10.1530/JOE-18-0598 (c) 2019 Society for Endocrinology Published by Bioscientifica Ltd. Printed in Great Britain 
resistance. Nature Medicine 21 159-165. (https://doi.org/10.1038/ nm.3760)

Fernandez-Cachon ML, Pedersen SL, Rigbolt KT, Zhang C, Fabricius K, Hansen HH, Elster L, Fink LN, Schafer M, Rhee NA, et al. 2018 Guanylin and uroguanylin mRNA expression is increased following Roux-en-Y gastric bypass, but guanylins do not play a significant role in body weight regulation and glycemic control. Peptides $10132-43$. (https://doi.org/10.1016/j.peptides.2017.12.024)

Finlin BS, Memetimin H, Confides AL, Kasza I, Zhu B, Vekaria HJ, Harfmann B, Jones KA, Johnson ZR, Westgate PM, et al. 2018 Human adipose beiging in response to cold and mirabegron. JCI Insight $\mathbf{3}$ 121510. (https://doi.org/10.1172/jci.insight.121510)

Fischer K, Ruiz HH, Jhun K, Finan B, Oberlin DJ, Van Der Heide V, Kalinovich AV, Petrovic N, Wolf Y, Clemmensen C, et al. 2017 Alternatively activated macrophages do not synthesize catecholamines or contribute to adipose tissue adaptive thermogenesis. Nature Medicine 23 623-630. (https://doi.org/ 10.1038/nm.4316)

Fisher FM, Kleiner S, Douris N, Fox EC, Mepani RJ, Verdeguer F, Wu J, Kharitonenkov A, Flier JS, Maratos-Flier E, et al. 2012 FGF21 regulates PGC-1alpha and browning of white adipose tissues in adaptive thermogenesis. Genes and Development 26 271-281. (https://doi. org/10.1101/gad.177857.111)

Folgueira C, Beiroa D, Callon A, Al-Massadi O, Barja-Fernandez S, Senra A, Ferno J, Lopez M, Dieguez C, Casanueva FF, et al. 2016 Uroguanylin action in the brain reduces weight gain in obese mice via different efferent autonomic pathways. Diabetes 65 421-432. (https://doi. org/10.2337/db15-0889)

Fox CS, Massaro JM, Hoffmann U, Pou KM, Maurovich-Horvat P, Liu CY, Vasan RS, Murabito JM, Meigs JB, Cupples LA, et al. 2007 Abdominal visceral and subcutaneous adipose tissue compartments: association with metabolic risk factors in the Framingham Heart Study. Circulation 116 39-48. (https://doi.org/10.1161/ CIRCULATIONAHA.106.675355)

Frontini A, Vitali A, Perugini J, Murano I, Romiti C, Ricquier D, Guerrieri M \& Cinti S 2013 White-to-brown transdifferentiation of omental adipocytes in patients affected by pheochromocytoma. Biochimica and Biophysica Acta 1831 950-959. (https://doi. org/10.1016/j.bbalip.2013.02.005)

Gaich G, Chien JY, Fu H, Glass LC, Deeg MA, Holland WL, Kharitonenkov A, Bumol T, Schilske HK \& Moller DE 2013 The effects of LY2405319, an FGF21 analog, in obese human subjects with type 2 diabetes. Cell Metabolism 18 333-340. (https://doi.org/10.1016/j. cmet.2013.08.005)

Gonzalez-Garcia I, Contreras C, Estevez-Salguero Á, Ruiz-Pino F, Colsh B, Pensado I, Linares-Pose L, Rial-Pensado E, Martinez De Morentin PB, Ferno J, et al. 2018 Estradiol regulates energy balance by ameliorating hypothalamic ceramide-induced ER stress. Cell Reports 25 413-423.e5. (https://doi.org/10.1016/j.celrep.2018.09.038)

Gudiksen A, Schwartz CL, Bertholdt L, Joensen E, Knudsen JG \& Pilegaard H 2016 Lack of skeletal muscle IL-6 affects pyruvate dehydrogenase activity at rest and during prolonged exercise. PLoS ONE 11 e0156460. (https://doi.org/10.1371/journal.pone.0156460)

Hanssen MJ, Broeders E, Samms RJ, Vosselman MJ, Van Der Lans AA, Cheng CC, Adams AC, Van Marken Lichtenbelt WD \& Schrauwen P $2015 a$ Serum FGF21 levels are associated with brown adipose tissue activity in humans. Scientific Reports 5 10275. (https://doi. org/10.1038/srep10275)

Hanssen MJ, Hoeks J, Brans B, van der Lans AA, Schaart G, van den Driessche JJ, Jörgensen JA, Boekschoten MV, Hesselink MK, Havekes B, et al. $2015 b$ Short-term cold acclimation improves insulin sensitivity in patients with type 2 diabetes mellitus. Nature Medicine 21 863-865. (https://doi.org/10.1038/nm.3891)

Hanssen MJ, van der Lans AA, Brans B, Hoeks J, Jardon KM, Schaart G, Mottaghy FM, Schrauwen P \& van Marken Lichtenbelt WD 2016
Short-term cold acclimation recruits brown adipose tissue in obese humans. Diabetes 65 1179-1189. (https://doi.org/10.2337/db15-1372)

Hecksteden A, Wegmann M, Steffen A, Kraushaar J, Morsch A, Ruppenthal S, Kaestner L \& Meyer T 2013 Irisin and exercise training in humans - results from a randomized controlled training trial. BMC Medicine 11 235. (https://doi.org/10.1186/1741-7015-11-235)

Hedesan OC, Fenzl A, Digruber A, Spirk K, Baumgartner-Parzer S, Bilban M, Kenner L, Vierhapper M, Elbe-Burger A \& Kiefer FW 2018 Parathyroid hormone induces a browning program in human white adipocytes. International Journal of Obesity [epub]. (https://doi. org/10.1038/s41366-018-0266-z)

Himms-Hagen J, Cui J, Danforth E, Jr, Taatjes DJ, Lang SS, Waters BL \& Claus TH 1994 Effect of Cl-316,243, a thermogenic beta 3-agonist, on energy balance and brown and white adipose tissues in rats. American Journal of Physiology 266 R1371-R1382. (https://doi.org/10.1152/ ajpregu.1994.266.4.R1371)

Jankovic A, Otasevic V, Stancic A, Buzadzic B, Korac A \& Korac B 2017 Physiological regulation and metabolic role of browning in white adipose tissue. Hormone Molecular Biology and Clinical Investigation 31 1868-1891. (https://doi.org/10.1515/hmbci-2017-0034)

Kern PA, Finlin BS, Zhu B, Rasouli N, Mcgehee RE, Jr, Westgate PM \& Dupont-Versteegden EE 2014 The effects of temperature and seasons on subcutaneous white adipose tissue in humans: evidence for thermogenic gene induction. Journal of Clinical Endocrinology and Metabolism 99 E2772-E2779. (https://doi.org/10.1210/jc.2014-2440)

Kiefer FW 2016 Browning and thermogenic programing of adipose tissue. Best Practice and Research: Clinical Endocrinology and Metabolism 30 479-485. (https://doi.org/10.1016/j.beem.2016.09.003)

Kir S, White JP, Kleiner S, Kazak L, Cohen P, Baracos VE \& Spiegelman BM 2014 Tumour-derived PTH-related protein triggers adipose tissue browning and cancer cachexia. Nature 513 100-104. (https://doi org/10.1038/nature13528)

Kir S, Komaba H, Garcia AP, Economopoulos KP, Liu W, Lanske B, Hodin RA \& Spiegelman BM 2016 PTH/PTHrP receptor mediates cachexia in models of kidney failure and cancer. Cell Metabolism 23 315-323. (https://doi.org/10.1016/j.cmet.2015.11.003)

Knudsen JG, Murholm M, Carey AL, Bienso RS, Basse AL, Allen TL, Hidalgo J, Kingwell BA, Febbraio MA, Hansen JB, et al. 2014 Role of IL-6 in exercise training- and cold-induced UCP1 expression in subcutaneous white adipose tissue. PLOS ONE 9 e84910. (https://doi. org/10.1371/journal.pone.0084910)

Kurdiova T, Balaz M, Vician M, Maderova D, Vlcek M, Valkovic L, Srbecky M, Imrich R, Kyselovicova O, Belan V, et al. 2014 Effects of obesity, diabetes and exercise on Fndc5 gene expression and irisin release in human skeletal muscle and adipose tissue: in vivo and in vitro studies. Journal of Physiology 592 1091-1107. (https://doi. org/10.1113/jphysiol.2013.264655)

Lee YH, Petkova AP, Mottillo EP \& Granneman JG 2012 In vivo identification of bipotential adipocyte progenitors recruited by beta3adrenoceptor activation and high-fat feeding. Cell Metabolism $\mathbf{1 5}$ 480-491. (https://doi.org/10.1016/j.cmet.2012.03.009)

Lee P, Linderman JD, Smith S, Brychta RJ, Wang J, Idelson C, Perron RM, Werner CD, Phan GQ, Kammula US, et al. 2014a Irisin and FGF21 are cold-induced endocrine activators of brown fat function in humans. Cell Metabolism 19 302-309. (https://doi.org/10.1016/j. cmet.2013.12.017)

Lee P, Smith S, Linderman J, Courville AB, Brychta RJ, Dieckmann W, Werner CD, Chen KY \& Celi FS $2014 b$ Temperature-acclimated brown adipose tissue modulates insulin sensitivity in humans. Diabetes 63 3686-3698. (https://doi.org/10.2337/db14-0513)

Lee YH, Petkova AP, Konkar AA \& Granneman JG 2015 Cellular origins of cold-induced brown adipocytes in adult mice. FASEB Journal 29 286-299. (https://doi.org/10.1096/fj.14-263038)

Leitner BP, Huang S, Brychta RJ, Duckworth CJ, Baskin AS, Mcgehee S, Tal I, Dieckmann W, Gupta G, Kolodny GM, et al. 2017 Mapping of https://joe.bioscientifica.com

https://doi.org/10.1530/JOE-18-0598 (c) 2019 Society for Endocrinology Published by Bioscientifica Ltd. Printed in Great Britain 
human brown adipose tissue in lean and obese young men. PNAS 114 8649-8654. (https://doi.org/10.1073/pnas.1705287114)

Li T \& Chiang JY 2015 Bile acids as metabolic regulators. Current Opinion in Gastroenterology 31 159-165. (https://doi.org/10.1097/ MOG.0000000000000156)

Li G, Xie C, Lu S, Nichols RG, Tian Y, Li L, Patel D, Ma Y, Brocker CN, Yan T, et al. 2017 Intermittent fasting promotes white adipose browning and decreases obesity by shaping the gut microbiota. Cell Metabolism 26 672.e4-685.e4. (https://doi.org/10.1016/j. cmet.2017.08.019)

Li S, Li Y, Xiang L, Dong J, Liu M \& Xiang G 2018 Sildenafil induces browning of subcutaneous white adipose tissue in overweight adults. Metabolism: Clinical and Experimental 78 106-117. (https://doi. org/10.1016/j.metabol.2017.09.008)

Liu J, Fox CS, Hickson DA, May WD, Hairston KG, Carr JJ \& Taylor HA 2010 Impact of abdominal visceral and subcutaneous adipose tissue on cardiometabolic risk factors: the Jackson Heart Study. Journal of Clinical Endocrinology and Metabolism 95 5419-5426. (https://doi. org/10.1210/jc.2010-1378)

Liu D, Ceddia RP \& Collins S 2018 Cardiac natriuretic peptides promote adipose 'browning' through mTOR complex-1. Molecular Metabolism 9 192-198. (https://doi.org/10.1016/j.molmet.2017.12.017)

Lopez M, Varela L, Vazquez MJ, Rodriguez-Cuenca S, Gonzalez CR, Velagapudi VR, Morgan DA, Schoenmakers E, Agassandian K, Lage R, et al. 2010 Hypothalamic AMPK and fatty acid metabolism mediate thyroid regulation of energy balance. Nature Medicine 16 1001-1008. (https://doi.org/10.1038/nm.2207)

Lopez M, Nogueiras R, Tena-Sempere M \& Dieguez C 2016 Hypothalamic AMPK: a canonical regulator of whole-body energy balance. Nature Reviews: Endocrinology 12 421-432. (https://doi.org/10.1038/ nrendo.2016.67)

Lynes MD, Leiria LO, Lundh M, Bartelt A, Shamsi F, Huang TL, Takahashi H, Hirshman MF, Schlein C, Lee A, et al. 2017 The coldinduced lipokine 12,13-diHOME promotes fatty acid transport into brown adipose tissue. Nature Medicine 23 631-637. (https://doi. org/10.1038/nm.4297)

Martinez De Morentin PB, Gonzalez-Garcia I, Martins L, Lage R, Fernandez-Mallo D, Martinez-Sanchez N, Ruiz-Pino F, Liu J, Morgan DA, Pinilla L, et al. 2014 Estradiol regulates brown adipose tissue thermogenesis via hypothalamic AMPK. Cell Metabolism 20 41-53. (https://doi.org/10.1016/j.cmet.2014.03.031)

Martinez-Sanchez N, Moreno-Navarrete JM, Contreras C, Rial-Pensado E, Ferno J, Nogueiras R, Dieguez C, Fernandez-Real JM \& Lopez M $2017 a$ Thyroid hormones induce browning of white fat. Journal of Endocrinology 232 351-362. (https://doi.org/10.1530/JOE-16-0425)

Martinez-Sanchez N, Seoane-Collazo P, Contreras C, Varela L, Villarroya J, Rial-Pensado E, Buque X, Aurrekoetxea I, Delgado TC, VazquezMartinez R, et al. 2017b Hypothalamic AMPK-ER stress-JNK1 axis mediates the central actions of thyroid hormones on energy balance. Cell Metabolism 26 212.e12-229.e12. (https://doi.org/10.1016/j. cmet.2017.06.014)

Matsushita M, Yoneshiro T, Aita S, Kameya T, Sugie H \& Saito M 2014 Impact of brown adipose tissue on body fatness and glucose metabolism in healthy humans. International Journal of Obesity 38 812-817. (https://doi.org/10.1038/ijo.2013.206)

Moraes C, Leal VO, Marinho SM, Barroso SG, Rocha GS, Boaventura GT \& Mafra D 2013 Resistance exercise training does not affect plasma irisin levels of hemodialysis patients. Hormone and Metabolic Research 45 900-904. (https://doi.org/10.1055/s-0033-1354402)

Moreno-Aliaga MJ, Perez-Echarri N, Marcos-Gomez B, Larequi E, Gil-Bea FJ, Viollet B, Gimenez I, Martinez JA, Prieto J \& Bustos M 2011 Cardiotrophin-1 is a key regulator of glucose and lipid metabolism. Cell Metabolism 14 242-253. (https://doi.org/10.1016/j. cmet.2011.05.013)

Mottillo EP, Desjardins EM, Crane JD, Smith BK, Green AE, Ducommun S, Henriksen TI, Rebalka IA, Razi A, Sakamoto K, et al. 2016 Lack of adipocyte AMPK exacerbates insulin resistance and hepatic steatosis through brown and beige adipose tissue function. Cell Metabolism $\mathbf{2 4}$ 118-129. (https://doi.org/10.1016/j.cmet.2016.06.006)

Murano I, Barbatelli G, Giordano A \& Cinti S 2009 Noradrenergic parenchymal nerve fiber branching after cold acclimatisation correlates with brown adipocyte density in mouse adipose organ. Journal of Anatomy 214 171-178. (https://doi.org/10.1111/j.14697580.2008.01001.x)

Muzik O, Mangner TJ, Leonard WR, Kumar A, Janisse J \& Granneman JG 201315 O PET measurement of blood flow and oxygen consumption in cold-activated human brown fat. Journal of Nuclear Medicine 54 523-531. (https://doi.org/10.2967/jnumed.112.111336)

Nedergaard J, Bengtsson T \& Cannon B 2007 Unexpected evidence for active brown adipose tissue in adult humans. American Journal of Physiology: Endocrinology and Metabolism 293 E444-E452. (https://doi. org/10.1152/ajpendo.00691.2006)

Neeland IJ, Ayers CR, Rohatgi AK, Turer AT, Berry JD, Das SR, Vega GL, Khera A, Mcguire DK, Grundy SM, et al. 2013 Associations of visceral and abdominal subcutaneous adipose tissue with markers of cardiac and metabolic risk in obese adults. Obesity 21 E439-E447. (https:// doi.org/10.1002/oby.20135)

Nguyen KD, Qiu Y, Cui X, Goh YP, Mwangi J, David T, Mukundan L, Brombacher F, Locksley RM \& Chawla A 2011 Alternatively activated macrophages produce catecholamines to sustain adaptive thermogenesis. Nature 480 104-108. (https://doi.org/10.1038/ nature10653)

Nguyen NLT, Barr CL, Ryu V, Cao Q, Xue B \& Bartness TJ 2017 Separate and shared sympathetic outflow to white and brown fat coordinately regulates thermoregulation and beige adipocyte recruitment. American Journal of Physiology: Regulatory, Integrative and Comparative Physiology 312 R132-R145. (https://doi.org/10.1152/ ajpregu.00344.2016)

Nisoli E, Clementi E, Paolucci C, Cozzi V, Tonello C, Sciorati C, Bracale R, Valerio A, Francolini M, Moncada S, et al. 2003 Mitochondrial biogenesis in mammals: the role of endogenous nitric oxide. Science 299 896-899. (https://doi.org/10.1126/science.1079368)

Nisoli E, Falcone S, Tonello C, Cozzi V, Palomba L, Fiorani M, Pisconti A, Brunelli S, Cardile A, Francolini M, et al. 2004 Mitochondrial biogenesis by NO yields functionally active mitochondria in mammals. PNAS 101 16507-16512. (https://doi.org/10.1073/ pnas.0405432101)

Norheim F, Langleite TM, Hjorth M, Holen T, Kielland A, Stadheim HK, Gulseth HL, Birkeland KI, Jensen J \& Drevon CA 2014 The effects of acute and chronic exercise on PGC-1alpha, irisin and browning of subcutaneous adipose tissue in humans. FEBS Journal 281 739-749. (https://doi.org/10.1111/febs.12619)

Pirzgalska RM, Seixas E, Seidman JS, Link VM, Sanchez NM, Mahu I, Mendes R, Gres V, Kubasova N, Morris I, et al. 2017 Sympathetic neuron-associated macrophages contribute to obesity by importing and metabolizing norepinephrine. Nature Medicine 23 1309-1318. (https://doi.org/10.1038/nm.4422)

Qiu Y, Nguyen KD, Odegaard JI, Cui X, Tian X, Locksley RM, Palmiter RD \& Chawla A 2014 Eosinophils and type 2 cytokine signaling in macrophages orchestrate development of functional beige fat. Cell 157 1292-1308. (https://doi.org/10.1016/j.cell.2014.03.066)

Qiu S, Cai X, Sun Z, Schumann U, Zugel M \& Steinacker JM 2015 Chronic exercise training and circulating irisin in adults: a meta-analysis. Sports Medicine 45 1577-1588. (https://doi.org/10.1007/s40279-014-0293-4)

Rao RR, Long JZ, White JP, Svensson KJ, Lou J, Lokurkar I, Jedrychowski MP, Ruas JL, Wrann CD, Lo JC, et al. 2014 Meteorinlike is a hormone that regulates immune-adipose interactions to increase beige fat thermogenesis. Cell 157 1279-1291. (https://doi. org/10.1016/j.cell.2014.03.065)

Roh HC, Tsai LTY, Shao M, Tenen D, Shen Y, Kumari M, Lyubetskaya A, Jacobs C, Dawes B, Gupta RK, et al. 2018 Warming induces significant reprogramming of beige, but not brown, adipocyte cellular identity. https://joe.bioscientifica.com

https://doi.org/10.1530/JOE-18-0598 (c) 2019 Society for Endocrinology Published by Bioscientifica Ltd. Printed in Great Britain 
Cell Metabolism 27 1121.e5-1137.e5. (https://doi.org/10.1016/j. cmet.2018.03.005)

Rosell M, Kaforou M, Frontini A, Okolo A, Chan YW, Nikolopoulou E, Millership S, Fenech ME, Macintyre D, Turner JO, et al. 2014 Brown and white adipose tissues: intrinsic differences in gene expression and response to cold exposure in mice. American Journal of Physiology: Endocrinology and Metabolism 306 E945-E964. (https://doi. org/10.1152/ajpendo.00473.2013)

Rosenwald M, Perdikari A, Rulicke T \& Wolfrum C 2013 Bi-directional interconversion of Brite and white adipocytes. Nature Cell Biology $\mathbf{1 5}$ 659-667. (https://doi.org/10.1038/ncb2740)

Ruan HB, Dietrich MO, Liu ZW, Zimmer MR, Li MD, Singh JP, Zhang K, Yin R, Wu J, Horvath TL, et al. 2014 O-GlcNAc transferase enables AgRP neurons to suppress browning of white fat. Cell 159 306-317. (https://doi.org/10.1016/j.cell.2014.09.010)

Saito M, Okamatsu-Ogura Y, Matsushita M, Watanabe K, Yoneshiro T, Nio-Kobayashi J, Iwanaga T, Miyagawa M, Kameya T, Nakada K, et al. $2009 a$ High incidence of metabolically active brown adipose tissue in healthy adult humans: effects of cold exposure and adiposity. Diabetes 58 1526-1531. (https://doi.org/10.2337/db09-0530)

Saito M, Okamatsu-Ogura Y, Matsushita M, Watanabe K, Yoneshiro T, Nio-Kobayashi J, Iwanaga T, Miyagawa M, Kameya T, Nakada K, et al. $2009 b$ High incidence of metabolically active brown adipose tissue in healthy adult humans: effects of cold exposure and adiposity. Diabetes 58 1526-1531. (https://doi.org/10.2337/db09-0530)

Schlein C, Talukdar S, Heine M, Fischer AW, Krott LM, Nilsson SK, Brenner MB, Heeren J \& Scheja L 2016 FGF21 lowers plasma triglycerides by accelerating lipoprotein catabolism in white and brown adipose tissues. Cell Metabolism 23 441-453. (https://doi. org/10.1016/j.cmet.2016.01.006)

Seale P, Conroe HM, Estall J, Kajimura S, Frontini A, Ishibashi J, Cohen P, Cinti S \& Spiegelman BM 2011 Prdm16 determines the thermogenic program of subcutaneous white adipose tissue in mice. Journal of Clinical Investigation 121 96-105. (https://doi.org/10.1172/ JCI44271)

Sengenes C, Berlan M, De Glisezinski I, Lafontan M \& Galitzky J 2000 Natriuretic peptides: a new lipolytic pathway in human adipocytes. FASEB Journal 14 1345-1351. (https://doi.org/10.1096/ fasebj.14.10.1345)

Sengenes C, Bouloumie A, Hauner H, Berlan M, Busse R, Lafontan M \& Galitzky J 2003 Involvement of a cGMP-dependent pathway in the natriuretic peptide-mediated hormone-sensitive lipase phosphorylation in human adipocytes. Journal of Biological Chemistry 278 48617-48626. (https://doi.org/10.1074/jbc.M303713200)

Seoane-Collazo P, Roa J, Rial-Pensado E, Linares-Pose L, Beiroa D, Ruiz-Pino F, Lopez-Gonzalez T, Morgan DA, Pardavila JÁ, SanchezTapia MJ, et al. 2018 SF1-specific AMPKalpha1 deletion protects against diet-induced obesity. Diabetes 67 2213-2226. (https://doi. org/10.2337/db17-1538)

Sidossis LS, Porter C, Saraf MK, Børsheim E, Radhakrishnan RS, Chao T, Ali A, Chondronikola M, Mlcak R, Finnerty CC, et al. 2015 Browning of subcutaneous white adipose tissue in humans after severe adrenergic stress. Cell Metabolism 22 219-227. (https://doi. org/10.1016/i.cmet.2015.06.022)

Staiger H, Keuper M, Berti L, Hrabe De Angelis M \& Haring HU 2017 Fibroblast growth factor 21-metabolic role in mice and men. Endocrine Reviews 38 468-488. (https://doi.org/10.1210/er.2017-00016)

Stanford KI, Middelbeek RJW, Townsend KL, An D, Nygaard EB, Hitchcox KM, Markan KR, Nakano K, Hirshman MF, Tseng YH, et al. 2013 Brown adipose tissue regulates glucose homeostasis and insulin sensitivity. Journal of Clinical Investigation 123 215-223. (https://doi. org/10.1172/JCI62308)

Talukdar S, Zhou Y, Li D, Rossulek M, Dong J, Somayaji V, Weng Y, Clark R, Lanba A, Owen BM, et al. 2016 A long-acting FGF21 molecule, PF-05231023, decreases body weight and improves lipid profile in non-human primates and type 2 diabetic subjects. Cell Metabolism 23 427-440. (https://doi.org/10.1016/j.cmet.2016.02.001)

Teodoro JS, Zouhar P, Flachs P, Bardova K, Janovska P, Gomes AP, Duarte FV, Varela AT, Rolo AP, Palmeira CM, et al. 2014 Enhancement of brown fat thermogenesis using chenodeoxycholic acid in mice. International Journal of Obesity 38 1027-1034. (https://doi. org/10.1038/ijo.2013.230)

Tran TT, Yamamoto Y, Gesta S \& Kahn CR 2008 Beneficial effects of subcutaneous fat transplantation on metabolism. Cell Metabolism 7 410-420. (https://doi.org/10.1016/j.cmet.2008.04.004)

Valentino MA, Lin JE, Snook AE, Li P, Kim GW, Marszalowicz G, Magee MS, Hyslop T, Schulz S \& Waldman SA 2011 A uroguanylinGUCY2C endocrine axis regulates feeding in mice. Journal of Clinical Investigation 121 3578-3588. (https://doi.org/10.1172/JCI57925)

van der Lans AA, Hoeks J, Brans B, Vijgen GH, Visser MG, Vosselman MJ, Hansen J, Jörgensen JA, Wu J, Mottaghy FM, et al. 2013 Cold acclimation recruits human brown fat and increases nonshivering thermogenesis. Journal of Clinical Investigation 123 3395-3403. (https://doi.org/10.1172/JCI68993)

Van Der Stelt I, Hoevenaars F, Siroka J, De Ronde L, Friedecky D, Keijer J \& Van Schothorst E 2017 Metabolic response of visceral white adipose tissue of obese mice exposed for 5 days to human room temperature compared to mouse thermoneutrality. Frontiers in Physiology 8179. (https://doi.org/10.3389/fphys.2017.00179)

Van Marken Lichtenbelt WD, Vanhommerig JW, Smulders NM, Drossaerts JM, Kemerink GJ, Bouvy ND, Schrauwen P \& Teule GJ 2009 Cold-activated brown adipose tissue in healthy men. New England Journal of Medicine 360 1500-1508. (https://doi.org/10.1056/ NEJMoa0808718)

Vargas-Castillo A, Fuentes-Romero R, Rodriguez-Lopez LA, Torres N \& Tovar AR 2017 Understanding the biology of thermogenic fat: is browning a new approach to the treatment of obesity? Archives of Medical Research 48 401-413. (https://doi.org/10.1016/j. arcmed.2017.10.002)

Vazquez P, Hernandez-Sanchez C, Escalona-Garrido C, Pereira L, Contreras C, Lopez M, Balsinde J, De Pablo F \& Valverde ÁM 2018 Increased FGF21 in brown adipose tissue of tyrosine hydroxylase heterozygous mice: implications for cold adaptation. Journal of Lipid Research 59 2308-2320. (https://doi.org/10.1194/jlr.M085209)

Vergnes L, Davies GR, Lin JY, Yeh MW, Livhits MJ, Harari A, Symonds ME, Sacks HS \& Reue K 2016 Adipocyte browning and higher mitochondrial function in periadrenal but not SC fat in pheochromocytoma. Journal of Clinical Endocrinology and Metabolism 101 4440-4448. (https://doi.org/10.1210/jc.2016-2670)

Verrijken A, Francque S, Mertens I, Talloen M, Peiffer F \& Van Gaal L 2010 Visceral adipose tissue and inflammation correlate with elevated liver tests in a cohort of overweight and obese patients. International Journal of Obesity 34 899-907. (https://doi.org/10.1038/ ijo.2010.4)

Virtanen KA, Lidell ME, Orava J, Heglind M, Westergren R, Niemi T, Taittonen M, Laine J, Savisto NJ, Enerbäck S, et al. 2009 Functional brown adipose tissue in healthy adults. New England Journal of Medicine 360 1518-1525. (https://doi.org/10.1056/ NEJMoa0808949)

Wan Z, Perry CG, Macdonald T, Chan CB, Holloway GP \& Wright DC 2012 IL-6 is not necessary for the regulation of adipose tissue mitochondrial content. PLoS ONE 7 e51233. (https://doi.org/10.1371/ journal.pone.0051233)

Wang QA, Tao C, Gupta RK \& Scherer PE 2013 Tracking adipogenesis during white adipose tissue development, expansion and regeneration. Nature Medicine 19 1338-1344. (https://doi.org/10.1038/ nm.3324)

Worthmann A, John C, Rühlemann MC, Baguhl M, Heinsen FA, Schaltenberg N, Heine M, Schlein C, Evangelakos I, Mineo C, et al. 2017 Cold-induced conversion of cholesterol to bile acids in mice https://joe.bioscientifica.com https://doi.org/10.1530/JOE-18-0598 (c) 2019 Society for Endocrinology Published by Bioscientifica Ltd. Printed in Great Britain 
shapes the gut microbiome and promotes adaptive thermogenesis. Nature Medicine 23 839-849. (https://doi.org/10.1038/nm.4357)

Wree A, Kahraman A, Gerken G \& Canbay A 2011 Obesity affects the liver - the link between adipocytes and hepatocytes. Digestion $\mathbf{8 3}$ 124-133. (https://doi.org/10.1159/000318741)

Wu CS, Bongmba OYN, Yue J, Lee JH, Lin L, Saito K, Pradhan G, Li DP, Pan HL, Xu A, et al. 2017 Suppression of GHS-R in AgRP neurons mitigates diet-induced obesity by activating thermogenesis. International Journal of Molecular Sciences 18 E832. (https://doi. org/10.3390/ijms18040832)

Xu J, Lloyd DJ, Hale C, Stanislaus S, Chen M, Sivits G, Vonderfecht S, Hecht R, Li YS, Lindberg RA, et al. 2009 Fibroblast growth factor 21 reverses hepatic steatosis, increases energy expenditure, and improves insulin sensitivity in diet-induced obese mice. Diabetes 58 250-259. (https://doi.org/10.2337/db08-0392)

Xu L, Nagata N, Nagashimada M, Zhuge F, Ni Y, Chen G, Mayoux E, Kaneko S \& Ota T 2017 SGLT2 inhibition by empagliflozin promotes fat utilization and browning and attenuates inflammation and insulin resistance by polarizing M2 macrophages in diet-induced obese mice. EBioMedicine 20 137-149. (https://doi.org/10.1016/j. ebiom.2017.05.028)

Yao T, Deng Z, Gao Y, Sun J, Kong X, Huang Y, He Z, Xu Y, Chang Y, $\mathrm{Yu} \mathrm{KJ}$, et al. 2017 Ire1alpha in pomc neurons is required for thermogenesis and glycemia. Diabetes 66 663-673. (https://doi. org/10.2337/db16-0533)

Ye L, Wu J, Cohen P, Kazak L, Khandekar MJ, Jedrychowski MP, Zeng X, Gygi SP \& Spiegelman BM 2013 Fat cells directly sense temperature to activate thermogenesis. PNAS 110 12480-12485. (https://doi. org/10.1073/pnas.1310261110)

Yoneshiro T, Aita S, Matsushita M, Kameya T, Nakada K, Kawai Y \& Saito M 2011a Brown adipose tissue, whole-body energy expenditure, and thermogenesis in healthy adult men. Obesity 19 13-16. (https:// doi.org/10.1038/oby.2010.105)

Yoneshiro T, Aita S, Matsushita M, Okamatsu-Ogura Y, Kameya T, Kawai Y, Miyagawa M, Tsujisaki M \& Saito M 2011b Age-related decrease in cold-activated brown adipose tissue and accumulation of body fat in healthy humans. Obesity 19 1755-1760. (https://doi. org/10.1038/oby.2011.125)

Yoneshiro T, Aita S, Matsushita M, Kayahara T, Kameya T, Kawai Y, Iwanaga T \& Saito M 2013 Recruited brown adipose tissue as an antiobesity agent in humans. Journal of Clinical Investigation 123 3404-3408. (https://doi.org/10.1172/JCI67803)

Youngstrom TG \& Bartness TJ 1995 Catecholaminergic innervation of white adipose tissue in Siberian hamsters. American Journal of Physiology 268 R744-R751. (https://doi.org/10.1152/ajpregu.1995.268.3.R744)

Youngstrom TG \& Bartness TJ 1998 White adipose tissue sympathetic nervous system denervation increases fat pad mass and fat cell number. American Journal of Physiology 275 R1488-R1493. (https:// doi.org/10.1152/ajpregu.1998.275.5.R1488)

Zietak M, Kovatcheva-Datchary P, Markiewicz LH, Stahlman M, Kozak LP \& Backhed F 2016 Altered microbiota contributes to reduced dietinduced obesity upon cold exposure. Cell Metabolism 23 1216-1223. (https://doi.org/10.1016/j.cmet.2016.05.001)

Zingaretti MC, Crosta F, Vitali A, Guerrieri M, Frontini A, Cannon B, Nedergaard J \& Cinti S 2009 The presence of UCP1 demonstrates that metabolically active adipose tissue in the neck of adult humans truly represents brown adipose tissue. FASEB Journal 23 3113-3120. (https://doi.org/10.1096/fi.09-133546)

Zuriaga MA, Fuster JJ, Gokce N \& Walsh K 2017 Humans and mice display opposing patterns of 'browning' gene expression in visceral and subcutaneous white adipose tissue depots. Frontiers in Cardiovascular Medicine 4 27. (https://doi.org/10.3389/fcvm.2017.00027)

Received in final form 12 March 2019

Accepted 12 April 2019

Accepted Preprint published online 12 April 2019 https://joe.bioscientifica.com

https://doi.org/10.1530/JOE-18-0598 (c) 2019 Society for Endocrinology Published by Bioscientifica Ltd. 